\title{
Communication
}

\section{Virulence factors in Escherichia coli strains isolated from pigs in the Ribeirao Preto region, State of Sao Paulo, Brazil}

\author{
A.C.F.B. Carvalho
}

F.A. Avila $=$

R.P. Schocken-Iturrino ${ }^{2}$

\section{J.L. Quintana 2}

\section{P.E.G. Albertini $=$}

CARVALHO (A.C.F.B.), AVILA (F.A.), SHOCKEN-ITURRINO (R.P.), QUINTANA (J.L.), ALBERTINI (P.E.G.). Facteurs de virulence de souches d'Éscherichia coli isolées sur des porcs de la région de Ribeirao Preto dans l'État de Sao Paulo, Brésil. Revue Élev. Méd. vét. Pays trop., 1991, 44 (1) : 49-52

Trois cents écouvillons fécaux ont été réalisés sur des porcs atteints de diarrhée dans des fermes de la région de Ribeirao Preto dans l'État de Sao Paulo, au Brésil. Cent souches d'Escherichia coli ont été ainsi isolées et étudiées pour rechercher la production des entérotoxines thermolabiles (TL) et thermostables (STRa et STb) ainsi que la présence des facteurs de colonisation F4, F5, F6. Leur sensibilité a également été testée à l'égard de 14 agents antibiotiques et chimiothérapeutiques. La production des cntérotoxines a été la suivante pour 100 souches : 24 STb, cinq LT et trois Sta. Lors de la réaction d'hémagglutination mannose résistante, une souche a réagi positivement avec des globules reouges de mouton, de poulet, de cheval et d'homme. Une autre a réagi de même avec des globules rouges de cobaye, de mouton, de poulet, de cheval et d'homme. Mais ces deux souches ont cependant réagi négativement aux facteurs de colonisation F4, F5, F6 en présence du test d'agglutination sur lame. Toutes ces souches ont été résistantes à au moins un des antibiotiques étudiés, les pourcentages les plus élevés étant enregistrés avec la pénicilline, la tétracycline et la céphalosporine. Outre l'importance des facteurs de virulence normalement rencontrés avec les souches entérotoxigènes d'origine porcine $E$. coli, les résultats de la présente étude révèlent l'existence possible de nouveaux facteurs de colonisation, autres que F4, F5 et F6, dans la colibacillose porcine à $E$. coli dans la région de Ribeirao Preto. Mots clés : Porc - Escherichia coli - Pouvoir pathogène - Colibacillose - Brésil.

\section{Introduction}

Escherichia coli has been associated with different animal and human syndromes. Diarrhoea induced by $E$. coli has been pointed out as one of the most common infectious causes of mortality among newly weaned piglets and is also considered as the aetiological agent in more than half the cases of neonatal swine diarrhoea $(7,10,13,16,18)$.

The development of diarrhoea induced by $E$. coli depends on two major factors, i.e. production of enterotoxin and colonization of the small intestine $(11,16)$. The entero-

\footnotetext{
1. Department of Veterinary Preventive Medicine, Faculdade de Ciéncias Agrárias e Veterinárias, UNESP, 14870, Jaboticabal-SP, Brazil.
}

2. Department of Microbiology, Faculdade de Ciéncias Agrárias e Veterinárias, UNESP, 14870, Jaboticabal-SP, Brazil.

Reçu le 5.7.1990, accepté le 11.9.1990. toxins act on the intestinal mucosa, especially in the small intestine, causing diarrhoea of varying intensity (5). Among the diarrhoea inducing strains of $E$. coli are those producing thermolabile (LT) and thermostable (ST) enterotoxins.

Several studies have demonstrated that pili F4, F5 and F6 play an important role in the colonization of pig intestine by enterotoxigenic $E$. coli, with bacterial adherence to the intestinal wall being a critical point in this process. Although economic data are not available, according to the experience of many professionals $E$. coli-induced enteritis may be considered as the disease causing the heaviest losses to Brazilian pig breeders. This opinion is justified by the fact that this infection most often occurs in piglets aged one to ten days, causing rapid dehydration followed by death. On this basis, the objective of the present study was to determine the virulence factors of enterotoxigenic Escherichia coli involved in pig colibacillosis in the Ribeirao Preto region in the State of Sao Paulo (SP).

\section{Materials and Methods}

Three-hundred rectal swabs were taken from pigs with diarrhoea aged 1 to 10 and 25 to 35 days (post-weaning period) in farms in various areas of the Ribeirao Preto region in the State of Sao Paulo (SP).

\section{Isolation and chemical identification}

The faecal samples were inoculated into McConkey agar and incubated at $37{ }^{\circ} \mathrm{C}$ for $24 \mathrm{~h}$. Typical $E$. coli colonies were identified by the following tests : lactose fermentation, indole production, methyl red and Voges \& Proskauer reactions, citrate utilization, urease formation and hydrosulfide gas $\left(\mathrm{H}_{2} \mathrm{~S}\right)$ production. Readings were made after 24 hours of incubation at $37^{\circ} \mathrm{C}$.

\section{Serological identification}

E. coli strains were identified serologically using polyvalent $\mathrm{OK}$ rabbit antiserum by the slide agglutination test using three different serum pools :

- pool I consisted of sera against strains E 68I (0141: K85ab : K88ab), E 145 (0141 : K85ab), P 155 (0149 K91: K88ac), E 68 II (0141: K85ab : K88ac), and P 307 $(08: \mathrm{K} 87: 88 \mathrm{ab})$;

- pool II consisted of P 104 (0139 : K82), E 65 (045 K"65"), V 17 (0157 : "V17" : K88ac), E 57 (0138: K81), G 491 (0138: K81: 88ac) and G 1253 (0147: K89 : $88 \mathrm{ac})$;

- pool III consisted of P 16 (09: K103), Moon 637 (064 K?), Troyer (09: K35) and Moon 431 (0101: K30: K99).

\section{Enterotoxin detection}

STa : $E$. coli strains were cultured in a brain heart infusion $(\mathrm{BHI})$ broth on a water bath with shaking at 150-200 rpm, at $37{ }^{\circ} \mathrm{C}$ for $18 \mathrm{~h}$ and then centrifuged. Evans blue (2\%) was added to the supernatant and $0.1 \mathrm{ml}$ of the mixture was inoculated intragastrically into groups of 4 mice aged 3 to 4 days leaving one mouse as a control, according to the technique of DEAN (4). 
$\mathrm{STb}$ : strains were cultured in $\mathrm{BHI}$ broth on a water bath with shaking at $150-200 \mathrm{rpm}$, at $37^{\circ} \mathrm{C}$ for $18 \mathrm{~h}$ and then centrifuged for the determination of STb enterotoxin. The method used was that of the ligated loop from 6-8 week old piglets (9). The animals were submitted to laparotomy, the small intestine exposed, the intestinal lumen washed with physiological saline, the strains inoculated and the intestinal loops ligated. Ten $\mathrm{ml}$ of culture supernatant per loop were inoculated into a total of 15 to 20 $10 \mathrm{~cm}$ long loops. After $18 \mathrm{~h}$, the animals were sacrificed and loops were examined for the presence of dilatation and the ratio of fluid volume to loop length was calculated for each loop. Values of 1.0 or more were considered as positive.

LT : thermolabile enterotoxin was detected by radial immunohaemolysis as described by YANO (17).

\section{Detection of colonization factors}

For the detection of $\mathrm{F} 4$ adhesin, the E.coli strains were cultured in phosphated glucose-agar (12). Cultures to be examined for $\mathrm{F} 5$ adhesin were inoculated in Minca medium (12) and those to be examined for F6 adhesin were cultured on blood-agar (14). All media were incubated at $37{ }^{\circ} \mathrm{C}$ for $24 \mathrm{~h}$. Five colonies per plate were tested individually against purified anti-F4, anti-F5 and anti-F6 sera by slide agglutination.

\section{Mannose-resistant haemagglutination (MRHA)}

E. coli strains were cultured in Minca agar and incubated at 36 and $16{ }^{\circ} \mathrm{C}$ for 24 and $72 \mathrm{~h}$, respectively, and the bacterial cells were resuspended in PBS. Sheep, pig, guinea pig, horse, chicken and human red cells were resuspended at a concentration of $3 \%$. One drop of bacterial suspension was mixed with one drop of red cells, with or without a $1.5 \%$ mannose solution. The mixture was incubated at $0{ }^{\circ} \mathrm{C}$ for a few minutes and a reading of the results was undertaken (1).

\section{Bacterial sensitivity to antibiotics} and chemotherapeutic agents

All $E$. coli strains were submitted to the bacterial sensitivity test in the presence of the following antibiotics and chemotherapeutic agents : nalidixic acid, ampicillin, cephalotin, chloramphenycol, erythromycin, streptomycin, gentamicin, kanamycin, lincomycin, penicillin, novobiocin, neomycin, nitrofurantoin and tetracycline. The method used was that of BAUER (2).

\section{Results}

Of the 300 faecal swabs obtained from pigs with diarrhoea in the Ribeirao Preto region (SP), 100 E. coli strains were isolated. Table I shows the distribution of virulence factors among strains. Only three $(3.0 \%)$ of the 100 strains examined produced enterotoxin STa, 24 (24\%) produced STb, and five produced enterotoxin LT. Table I also shows that colonization factor F4 was present in 3 of the 5 strains that produced enterotoxin LT, in 6 of the STb+ strains, and in 2 of the STa+ strains. Eight $\mathrm{F} 5+$ strains produced enterotoxin $\mathrm{STb}$ and 1 produced enterotoxin STa. Five F4+, $12 \mathrm{~F} 5+$ and $1 \mathrm{~F} 6+$ strains were not enterotoxigenic. Twelve strains without colonization factors produced enterotoxins, and 50 (50.0\%) of all $E$. colistrains examined were not enterotoxigenic.

TABLE I Virulence factors in 100 Escherichia coli strains isolated from pigs with diarrhoea in the Ribeirão Preto region, State of São Paulo.

\begin{tabular}{|l|c|r|r|r|c|}
\hline \multirow{3}{*}{ Enterotoxin } & \multirow{2}{*}{$\begin{array}{c}\text { No. of positive strains/ } \\
\text { total no. of strains (\%) }\end{array}$} & \multicolumn{2}{|c|}{ Colonization } & \multicolumn{2}{c|}{ Factors } \\
\cline { 3 - 6 } & & $F^{+}$ & $F^{+}$ & $F^{+}$ & $F^{-}, F^{-}, F^{-}$ \\
\hline LT & $5 / 100$ & 3 & 0 & 0 & 2 \\
STb & $24 / 100$ & 6 & 8 & 0 & 10 \\
STa & $3 / 100$ & 2 & 1 & 0 & 0 \\
ECET $^{*}$ & $68 / 100$ & 5 & 12 & 1 & 50 \\
\hline Total & 100 & 16 & 21 & 1 & 62 \\
\hline
\end{tabular}

* Enterotoxigenic Escherichia coli.

On the basis of the MRHA test, $100 \mathrm{E}$. coli strain's were divided into four groups (table II). Group A included a single strain which reacted positively with sheep, chicken, horse and human red cells. Group B included a single strain that reacted positively with sheep and chicken red cells and was positive in the slide agglutination test for

TABLE II MHRH patterns in Escherichia coli strains isolated from pigs with diarrhoea in the Ribeirão Preto region, State of São Paulo.

\begin{tabular}{|c|c|c|c|c|c|c|c|}
\hline \multirow{2}{*}{ Group } & \multirow{2}{*}{ No. of isolated strains } & \multicolumn{6}{|c|}{ Red blood cells } \\
\hline & & Guinea pig & Sheep & Bovine & Chicken & Horse & Human \\
\hline $\begin{array}{l}A \\
B \\
C \\
D\end{array}$ & $\begin{array}{c}i \\
i \\
i \\
97\end{array}$ & $\begin{array}{l}- \\
- \\
+ \\
-\end{array}$ & $\begin{array}{l}+ \\
+ \\
+ \\
+\end{array}$ & $\begin{array}{l}- \\
- \\
+ \\
-\end{array}$ & $\begin{array}{l}+ \\
+ \\
+ \\
-\end{array}$ & $\begin{array}{l}+ \\
\pm \\
+\end{array}$ & $\begin{array}{l}+ \\
+ \\
+\end{array}$ \\
\hline
\end{tabular}


colonization factor F5. Group C included a single strain that reacted positively with guinea pig, sheep bovine, chicken, horse and human red cells. In contrast, group D comprising 97 strains, was negative to all types of red cells. Group A and C strains were negative in the slide agglutination test for colonization factors F4, F5 and F6 and were not enterotoxigenic.

All strains submitted to the antibacterial sensitivity test were resistant to at least one antibiotic, the highest percentages being observed for resistance to penicillin $(82 \%)$, tetracycline (93\%) and cephalotin (72\%).

\section{Discussion}

On the basis of slide serum agglutination with the serum pool against the Escherichia coli serotypes that are enteropathogenic for pigs, only $100 \mathrm{E}$. coli strains were considered to be the primary cause of diarrhoea among 300 piglets examined.

The frequency of LT enterotoxin-producing strains $(5 \%)$, although relatively low did not differ from that reported by OLIVEIRA (15) in a study of $700 \mathrm{E}$. coli strains isolated from pig with diarrhoea in the city of Sao Paulo. Contrary to the high percentage $(18 \%)$ of STb strains isolated by CASTRO (3) from pigs in the Concordia region in the State of Santa Catarina, the present results showed that only $3.0 \%$ of the isolated $E$. coli strains produced STa enterotoxin. The high frequency of STb+ strains $(24.0 \%)$ in relation to the other enterotoxins shows the importance of this enterotoxin in the pathogeny of $E$. coli-induced enteritis in the Ribeirao Preto region. It should be pointed out that the frequency of enterotoxigenic strains with colonization factors F4, F5 or F6 represented almost two times the frequency of enterotoxigenic strains without these colonization factors. Of the 68 non-enterotoxigenic strains, 5 produced the $\mathrm{F} 4$ antigen, 12 produced the $\mathrm{F} 5$ antigen and one produced the F6 antigen. The fact that no STa+ strain produced colonization factor F6 contradicts GAASTRA and DE GRAAF (6) who reported that this colonization factor was only detected among STa strains originating from pigs.

Analysis of the results showed that most of the $E$. coli strains studied were simultaneously resistant to two or more drugs. No strain was sensitive to all drugs. Penicillin, tetracyclin and cephalotin were the antibiotics to which the strains were most resistant. This may possibly be due to the abusive and indiscriminate utilization of these drugs for veterinary purposes.

Two samples belonging to groups $A$ and $C$, respectively of the MRHA patterns were negative in the slide agglutination test for colonization factors F4, F5 and F6. This fact suggests the possible existence of new colonization factors others than F4, F5 and F6, participating in the pathogeny of $E$. coli-induced pigs enteritis in the Ribeirao Preto region.
CARVALHO (A.C.F.B.), AVILA (F.A.), SIIOCKEN-ITURRINO (R.P.), QUINTANA (J.L.), ALBERTINI (P.E.G.). Virulence factors in Escherichia coli strains isolated from pigs in the Ribeirao Preto region, State of Sao Paulo, Brazil. Revue Élev. Méd. vét. Pays trop., 1991, 44 (1) : 49-52

Three-hundred faecal swabs were obtained from pigs with diarrhoea in fanus localed in different areas of the Ribeirao Preto region in the State of Sao Paulo. One-hundred Escherichia coli strains were isolated and tested for production of thermolabile (TL) and thermostable (STRa and STb) enterotoxins, and for the presence of colonization factors F4, F5 and F6. The strains were also tested for sensitivty to 14 antibiotics and chemotherapeutic agents. Twenty-four Escherichia coli strains produced enterotoxin STb, 5 produced LT and 3 produccd STa. In the mannose-resistant haemagglutination reaction, one strain reacted positively with sheep, chicken, horse and human red blood cells and another reacted positively with guinea pig, shccp, chicken, horse and human red cells. However, both strains were negative for colonization factors F4, F5 and F6 when submitted to the slide agglutination test. All Escherichia coli strains were resistant to at least one antibiotic, the highest percentages being obtained for resistance to penicillin, tetracyclin and cephalotin. In addition to the importance of the virulence factors normally encountered in enterotoxigenic Escherichia coli strains from pigs, the present results show the possible existence of new colonization factors other than F4, F5 and F6 participating in $E$. coli-induced pigs colibacillosis in the Ribeirao Preto region. Key words : Pig - Escherichia coli - Pathogenicity - Colibacillosis - Brazil.

\section{References}

1. AVILA (F.A.), SCHOCKEN-ITURRINO (R.P.), LALLIER (R.), FAIRBROTHER (J.M.) JACQUES (M.). A new fimbrial antigen on Escherichia coli strains isolated from zebu (Bos indicus) calves with diarrhoea in Brazil. Vet. Rec., 1988, $123: 80-81$.

2. BAUER (A.W.), KIRBY (W.M.M.), SHERRIS (J.C.). Antibiotic susceptibility testing by standardized single disc method. Am. J. clin. Path., 1966 $45: 493-496$

3. CASTRO (A.F.P.), SERAFIN (M.B.), BRITO (J.R.F.), BACELLOS (D.S.E.N.), COLLI (I.A.G.). Virulence factors present in cultures of Escherichia coli isolated from pigs in the region of Concórdia, Santa Catarina, Brazil. Pesq. vet. brasil., 1984, 4 (3) : 109-114.

4. DEAN (A.G.), CHING (Y.C.), WILLIAMS (R.G.), HARDEN (L.B.) Test for Escherichia coli enterotoxin using infant mice : application in a study of diarrhoea in children in Honolulu. J. infect. Dis., 1972, 125 (4) : 407-411.

5. FRANCO (B.D.G.M.). Escherichia coli e os alimentos. Hig. Alim., 1983, $2(42): 13-15$

6. GAASTRA (W.), DE GRAAF (F.K.). Host specific fimbrial adhesins of non-invasive enteroxigenic Escherichia coli strains. Microbiol. Rev., 1982, 46: $129-171$

7. GOSSLING (J.), RHOADES (H.E.). Serologic types of Escherichia coli isolated from certain pigs with enteric disorders. Cornell Vet, , 1966, 56 : 344-359.

8. GUINÉE (P.A.M.), VELDKAMP (J.), JANSEN (W.H.). Improved Minca medium for the detection of K99 antigen in calf enterotoxigenic strains of Escherichia coli. Infect. Immun., 1977, 15:676678 .

9. GYLES (C.L.). Limitations of the infant mouse test for $E$. coli heat stable enterotoxin. Can. J. comp. Med., 1979, 43 : 371-379.

10. GYLES (C.L.), BARNUM (D.A.). A heat-labile enterotoxin from strains of Escherichia coli enteropathogenic for pigs. J. infect. Dis., 1969, 120 (4) : $419-426$

11. HADAD (J.J.), GYLES (C.L.). Scaning and transmission electron microscopic study of the small intestine of colostrum fed calves infected with selected strains of $E$. coli. Am. J. vet. Res., 1982, 43 (1) : 41-49.

12. JONES (G.W.). RLTTER (J.M.). The association of K88 antigens with haemagglutinating activity of porcine strains of E. coli. J. gen. Microbiol., 1974, 84: 135-144.

13. LUND (A.). FOSSUM (K.), LIVEN (E.). Serologic enterotoxin producing and biochemical properties of Escherichia coli isolated from piglets with neonatal diarrhoea in Norway. Acta vet. scand., 1982, 23 79-87.

14. NAGY (B.), MOON (H.W.), ISAACSON (R.E.). Colonization of porcine intestine by enterotoxigenic $E$. coli : selection of piliated forms in vivo, adhesion of piliated forms to epithelial cells in vitro and incidence of a pilus 


\section{Communication}

antigen among porcine enteropathogenic E. coli. Infect. Immun., 1977, 16 344-352.

15. OLIVEIRA (M.S.), PESTANA DE CASTRO (A.F.), SERAFIN (M.B.). Produçao de enterotoxinas e resistência a drogas em colibacilos isolados de suínos com diarréia. Rev. Microbiol., 1982, 13 (2) : 135-142.

16. SMITH (H.W.), HALLS (S.). Studies on Escherichia coli enterotoxin. J. Path. Bact., 1967, $93: 531-543$.
17. YANO (T.), OLIVEIRA (M.S.), FONTES (C.F.), ALMEIDA (A.C.P.), CASTRO (A.F.P.). Detection of heat-labile (LT) enterotoxin of enterotoxigenic Escherichia coli by the radial immune hemolysis test : a modification for clinical use. Med. Microbiol. Immun., 1982, 171 (3) : 171-178.

18. ZHU (B.), AHRENS (F.A.). Effect of berberine on intestinal secretion mediated by Escherichia coli heat-stable enterotoxin in jejunum of pigs. Am. J. vet. Res., 1982, 43 (9) : 1594-1598. 